\title{
Symptoms, unbearability and the nature of suffering in terminal cancer patients dying at home: a prospective primary care study
}

\author{
Cees DM Ruijs ${ }^{1,3^{*}}$, Ad JFM Kerkhof ${ }^{2}$, Gerrit van der Wal ${ }^{1}$ and Bregje D Onwuteaka-Philipsen ${ }^{1}$
}

\begin{abstract}
Background: Primary care physicians provide palliative home care. In cancer patients dying at home in the Netherlands (45\% of all cancer patients) euthanasia in about one out of every seven patients indicates unbearable suffering. Symptom prevalence, relationship between intensity of symptoms and unbearable suffering, evolvement of symptoms and unbearability over time and quality of unbearable suffering were studied in end-of-life cancer patients in primary care.
\end{abstract}

Methods: 44 general practitioners during three years recruited cancer patients estimated to die within six months. Every two months patients quantified intensity as well as unbearability of 69 symptoms with the State-of-Suffering$V(S O S-V)$. Also overall unbearable suffering was quantified. The five-point rating scale ranged from 1 (not at all) to 5 (hardly can be worse). For symptoms assessed to be unbearable the nature of the suffering was additionally investigated with open-ended questions. The final interviews were analyzed; for longitudinal evolvement also the pre-final interviews were analyzed. Symptom intensity scores 4 and 5 were defined to indicate high intensity. Symptom unbearability scores 4 and 5 were defined to indicate unbearable suffering. Two raters categorized the qualitative descriptions of unbearable suffering.

Results: Out of 148 requested patients 51\% participated; 64 patients were followed up until death. The SOS-V was administered at least once in 60 patients (on average 30 days before death) and at least twice in 33 patients. Weakness was the most frequent unbearable symptom (57\%). Pain was unbearable in $25 \%$. Pain, loss of control over one's life and fear of future suffering frequently were unbearable (89-92\%) when symptom intensity was high. Loss of control over one's life, vomiting and not being able to do important things frequently were unbearable (52-80\%) when symptom intensity was low. Unbearable weakness significantly increased between pre-final and final interview. Physical suffering, loss of meaning, loss of autonomy, experiencing to be a burden, fear of future suffering and worrying more frequently occurred in patients suffering unbearably overall.

Conclusions: Weakness was the most prevalent unbearable symptom in an end-of-life primary care cancer population. Physical suffering, loss of meaning and loss of autonomy more frequently occurred in patients who suffered unbearably overall.

\footnotetext{
* Correspondence: c.ruys3@kpnplanet.nl

'Department of Public and Occupational Health, Expertise Center for Palliative Care, VU University Medical Center, EMGO+Institute, van der Boechorststraat 7, 1081 BT Amsterdam, The Netherlands

${ }^{3}$ Primary Care Center De Greev, Grevelingenstraat 10, 3522 PR Utrecht, The Netherlands

Full list of author information is available at the end of the article
} 


\section{Background}

Many cancer patients in the end-stage of their disease prefer to die at home [1,2]. In the Netherlands $45 \%$ of all cancer patients die at home [3]. Palliative care for these patients is provided by primary care physicians. Of the remaining cancer deaths $31 \%$ occur in hospitals, $19 \%$ in care homes and $4 \%$ in hospices. Characteristics of primary palliative care include selection of patients with a preference to die at home, palliative care provided by a physician trained in general medicine, strong relationships between physicians and patients, care provided at home and dependent upon the possibilities of care at home, support by a home team, support by a specialized palliative care service and negative selection of cancer related emergencies [4-7]. The low prevalence of patients dying from cancer at home may interfere with effectively building up experience in palliative cancer care [8]. Primary care in the Netherlands is provided by nearly 9.000 general practitioners (GPs), 57\% of whom work part time [9]. A full time GP on average is responsible for palliative care for a cancer patient nearly three times a year [10].

Suffering in advanced cancer patients [11] may result in a desire for hastened death, or even a request for euthanasia or physician-assisted suicide [EPAS] [12-16]. In a few countries and states, including the Netherlands, EPAS has been legalized $[17,18]$. EPAS in legalized settings in majority is performed in primary care $[18,19]$. In relation to continuing societal and political debate about end-of-life decision making countries and states may face reevaluation of the legal position of EPAS [20,21]. The legalization of EPAS in the Netherlands requires presence of unbearable suffering, which needs to be assessed present by a physician who considers to perform EPAS in reaction to an explicit request for EPAS. Unbearable and hopeless suffering, no reasonable acceptable treatment alternative, a voluntary and wellconsidered request and consultation of an independent physician are among the compulsory criteria for EPAS [17]. EPAS is not permitted if the suffering is not assessed to be unbearable.

In professional literature the supposition holds that the proportion of patients who seriously consider EPAS is small $[15,22]$. Research seldom addresses unbearable suffering, nor EPAS, through prospective patient directed research. In the Netherlands in 201042.600 patients died as a consequence of cancer [23], of whom upon estimation 19.000 (45\%) [3] died at home. A total of 3550 EPAS (88\% of in total 4050 annual cases of EPAS) was performed in primary care [19] of which in $~ 2800$ cases (cancer is the diagnosis in $79 \%$ of cases of EPAS) the diagnosis was cancer. Thus, of end-of-life cancer patients cared for in primary care around one in seven died as a consequence of EPAS. This proportion is considerable and underscores the importance for a better understanding of the nature of unbearable suffering in various settings of care, which may contribute to competently providing care for patients who experience unbearable suffering.

Unbearable suffering seldom is investigated through prospective, patient directed research. Intensity of symptoms is considered to largely determine the suffering of incurable cancer patients [24]. However, a symptom that is unbearable for one person may be bearable for another. A prospective study in end-of-life cancer patients cared for in primary care was performed, addressing the following questions: Which are the most prevalent symptoms? What is the relationship between intensity of symptoms and unbearable suffering? How do symptoms and unbearable suffering evolve over time? Which qualitative characteristics of unbearable symptoms determine the nature of unbearable suffering?

\section{Methods}

Design

The study was conducted in Utrecht, a city with a population of 235000 people and 105 GPs. Eligible were terminal cancer patients expected to die within six months and expected to live at home (most of the time) until death cared for by a GP as the primary responsible physician. GPs requested eligible patients to participate. GPs estimated survival based upon signs of clinical deterioration of the patient.

Forty-four GPs, 59\% of whom worked part time, representing $42 \%$ of the GPs in the city, with practice locations dispersed throughout the city, requested eligible patients to participate. A researcher visited the consenting patients within a week and administered the baseline interview. Follow-up interviews were every two months, or sooner if the condition of a patient deteriorated. All interviews were at the patients' residence. The recruitment process was organized by a study coordinator. GPs were personally contacted every two months to identify newly eligible patients. Baseline characteristics of all eligible patients were registered. The interviewers were a physiotherapist (the study coordinator) and a GP (CDMR), both trained in interview techniques. The study protocol was approved by the Medical Ethics Committee at the VU University Medical Center. The recruitment process is described in detail elsewhere [25].

\section{Study population}

Patient recruitment was from May 2003 until May 2006, and follow-up continued until May 2007. Seventy six out of 148 invited patients (51\%) entered the interview study. The attrition rate was $8 \%$, caused by patients who stopped participating after one or more interviews and at the end of follow-up $8 \%$ of the patients were alive, leaving 64 patients 
with follow up until death. Main reasons for declining were unexpected rapid physical deterioration $(\mathrm{N}=27)$, considering participation too burdensome $(\mathrm{N}=20)$ and disliking to talk $(\mathrm{N}=15)$. Another 110 patients were not invited by the GP, because unexpected rapid disease progression resulted in a physical condition too debilitated to sustain an interview. Age, gender and type of cancer did not differ between the patients in and out of the interview sample. The prevalence of seriously depressed mood according to the GP was significantly lower in the interview sample: $5 \%$ versus $23 \%$ in the sample which declined participation and $14 \%$ in the sample which was not asked to participate because of a too debilitated physical condition [26]. The prevalence of depression was investigated, the results of which have been published separately; one patient suffered from a definite major depression [26].

\section{Measurement instrument: State-of-Suffering-V}

Quality of life instruments tend to focus on the intensity of symptoms. Health-related quality of life instruments have limitations in the context of research in dying patients [27]. No instrument existed to assess unbearable suffering. The State-of-Suffering-V (SOS-V) was developed [28], an instrument directed at assessing the experience of unbearable suffering of the whole person [11]. The SOS-V (Additional file 1) is a patient-driven instrument, which provides quantitative assessment of intensity and unbearability of physical, psychological, social and existential symptoms which may cause suffering. "Symptoms" refers to medical symptoms and circumstances as well as psychological, social and existential aspects which may cause suffering. This extended interpretation of symptoms is not uncommon in psychological research. The SOS-V addresses 69 symptoms in a framework of five functional domains: (I) medical signs and symptoms; (II) loss of function; (III) personal aspects; (IV) environment (psychosocial support, provided care) and (V) nature and prognosis of the disease [28].

Physical symptoms largely are present in the domain of medical signs and symptoms. The nature of suffering caused by a certain symptom cannot be predicted and therefore an a-priori distinction of suffering into physical, psychosocial, or existential dimensions cannot be made.

The SOS-V is a structured instrument in which the patient assesses intensity (or extent) and unbearability per symptom. A uniform 5-point scoring scale is employed, supported by a description: 1-not at all; 2-slightly; 3moderately; 4-seriously; 5-very seriously, hardly can be worse. Whenever a patient rates a 4 or 5 for unbearability of a symptom the interviewer through open-ended questions shortly further explores the experience and immediately writes down exact phrases of the answers. After rating the 69 symptoms the interviewer asks whether there are missing aspects which cause suffering, and rates these accordingly if present. Thereafter the patient is asked to rate overall unbearable suffering, considering all the present symptoms (same rating scale). Semi-structured administration of the SOS-V is permitted in the sense that the interviewer may follow a spontaneous other sequence of symptoms which a patients provides, as long as all symptoms are evaluated. The reference period in the study was the last two days. Limited field testing was performed. The development of the instrument, including analysis of validity, is described elsewhere [28]. Administration of the quantitative questions of the SOS-V most times was possible within 15 to 20 minutes [10,28].

\section{Analysis of relationship between intensity of symptoms and unbearable suffering}

The final SOS-V interviews before death in 60 patients were analyzed to investigate the relationship between intensity of a symptom and experienced unbearable suffering caused by that symptom. Four patients could not be evaluated because the interviewer considered the interview to burdensome and abandoned the interview.

Intensity of symptoms and unbearable suffering per symptom were analyzed dichotomously. A symptom with intensity rated 2 (slightly) or 3 (moderately) was defined to be of low intensity, while a symptom rated 4 (seriously) or 5 (hardly can be worse) was defined to be of high intensity. Symptoms in which unbearability was rated 1 (not at all), 2 (slightly) or 3 (moderately) were defined to be bearable, while symptoms rated 4 (seriously) or 5 (hardly can be worse) were defined to be unbearable. Overall unbearable suffering was defined accordingly. Presence of symptoms, intensity of symptoms and unbearability per symptom are presented as proportions of interviewed patients. Sample size (many clinically relevant symptoms were infrequently present) interfered with worthwhile statistical analysis. The relationship between intensity of symptoms and unbearable suffering is evaluated for the symptoms which (arbitrarily) were unbearable in at least $15 \%(\mathrm{n}=9)$ of the patients.

\section{Analysis of longitudinal data}

In 33 patients the SOS-V was administered at least two times. Intensity of symptoms, consequent unbearable suffering, and overall unbearable suffering, were analyzed for the symptoms in which unbearable suffering occurred most frequently (symptom unbearable in at least $15 \%$ of patients). For dichotomous analysis the same cut-off scores were used as described above. Confidence intervals for paired data per patient were calculated for statistical analysis.

\section{Analysis of subjective descriptions of unbearable suffering}

The answers of the patients to open questioning of why the suffering caused by a symptom was unbearable were 
analyzed. Patients in whom overall suffering was bearable were compared with patients in whom overall suffering was unbearable. A schedule was made of senses of suffering [29] considered important in end-of-life cancer patients (Table 1) [11,24,29-35]. Common emotional symptoms of psychological distress of individuals as they approach the terminal phase of illness [36,37] were additionally analyzed together. Two raters, a GP (CDMR) and an external clinical psychologist, rated all the qualitative answers. It was only permitted to give one rating per unbearable answer: the best fitting match. The raters started with independently rating the answers of five patients, after which the answers were compared. Fine tuning of the rating process was applied based upon exchange of arguments, after which the answers of the remaining patients were independently rated. Then the raters compared all differing ratings and applied one rating if consensus could be reached. Only equal ratings were used to compare patients in whom overall suffering was bearable with patients in whom overall suffering was unbearable. Consensus between the raters occurred in $86 \%$ of the analyzed descriptions of unbearable suffering. T-tests for mean prevalence were used for statistical analysis.

In the ratings which remained without consensus it was analyzed what caused the difference in rating. Based upon an analytical process two possibilities were identified. The first was different opinion about interpretation of the answer. The second was that the answer contained varied information, which made various ratings applicable. Persistent difference in rating in $9 \%$ was attributable to different interpretation of the answers of the patients. In $5 \%$ difference in rating occurred because the answers contained information which was applicable to more than one rating.

\section{Results}

\section{Study sample}

The studied sample consisted of 60 patients; 46 patients died within six months. The final interview on average was 30 days before death (SD 17 days); in 23\% the interview was within 2 weeks prior to death. The average age of the patients was 70 years (range 38-86), 52\% were female, 60\% were educated beyond elementary school, $63 \%$ were living alone, $77 \%$ had children and $62 \%$ were religious (protestant or catholic). The most prevalent malignancies were lung cancer (27\%) and gastro-intestinal cancer (25\%).

\section{Symptom prevalence and unbearable suffering}

Symptom prevalence was highest in the domains of medical symptoms, loss of function and personal aspects (Tables 2 and 3). Weakness was the most prevalent symptom in the domain of medical symptoms (93\%), and was unbearable in $57 \%$ of the patients. Other prevalent symptoms were tiredness, general discomfort, changed appearance and pain (72-87\%). Pain was unbearable in $25 \%$. Most prevalent in the functional domain were impaired routine daily activities and impaired leisure activities (just above $80 \%$ ), which were unbearable in half of the patients. Most prevalent in the domain of personal aspects was feeling dependent upon others (80\%), which was unbearable in $45 \%$ of patients. Other prevalent symptoms were not being able to do important things and trouble accepting the present situation (around 60\%). Loss of control over one's life was sensed in $30 \%$ of patients and was unbearable in $27 \%$. In the domain of environment the feeling that relatives considered the suffering too severe occurred in $33 \%$. In the domain of nature and prognosis of disease fear of future suffering occurred in $40 \%$.

Table 1 Categorization of qualitative data

\begin{tabular}{|c|c|}
\hline Category of suffering & Indications for assigning category \\
\hline Physical & Medical morbidity, the physical symptom itself, physical symptoms which result in physical experienced suffering \\
\hline Loss of meaning & Loss of: identity, capacity of self-fulfillment, communication, social role, social interaction, intimacy \\
\hline Loss of autonomy & $\begin{array}{l}\text { Suffering acknowledged to be caused by: loss of autonomous functioning or occurrence of dependency } \\
\text { (presence itself of loss of autonomy or of dependency is not sufficient to assign the category) }\end{array}$ \\
\hline Loss of dignity & Socially embarrassing symptoms, shame, body image concerns, not being taken seriously, worthlessness \\
\hline Loss of sexual role & Loss of capability of sexual functioning; loss of sexual role \\
\hline Fear of future suffering & Fear caused by awareness of potential suffering related to progress of disease \\
\hline Anxiety & Anxiety \\
\hline Death anxiety & $\begin{array}{l}\text { Anxiety related to awareness of the process of dying and what will go along with that, and anxiety } \\
\text { related to the actual dying process }\end{array}$ \\
\hline Depressiveness & Suffering caused by the presence of depressive thoughts \\
\hline Worrying & Negative thoughts which cannot be turned off \\
\hline Feeling tensed & Feeling tensed in mind or body \\
\hline Hopelessness & Loss of possibility of meaning \\
\hline Pointlessness & Total loss of meaning; nothing left \\
\hline
\end{tabular}


Table 2 Relationship between symptom intensity and unbearability for symptoms in the domain of: medical signs and symptoms ( $\mathrm{n}=60$ )

\begin{tabular}{|c|c|c|c|c|c|c|c|c|}
\hline & $\begin{array}{l}\text { Symptom present } \\
\% *(n)\end{array}$ & $\begin{array}{l}\text { Symptom high } \\
\text { intensity \%*(n) }\end{array}$ & $\begin{array}{l}\text { High intensity and } \\
\text { unbearable } \% *(n)\end{array}$ & $\begin{array}{l}\text { Percentage unbearable } \\
\text { when high intensity \% }\end{array}$ & $\begin{array}{l}\text { Symptom low } \\
\text { intensity } \% *(n)\end{array}$ & $\begin{array}{l}\text { Low intensity and } \\
\text { unbearable } \%(n)\end{array}$ & $\begin{array}{l}\text { Percentage unbearable } \\
\text { when low intensity \% }\end{array}$ & $\begin{array}{c}\text { Symptom } \\
\text { unbearable } \% *(n)\end{array}$ \\
\hline \multicolumn{9}{|l|}{$\begin{array}{l}\text { Domain I: Medical } \\
\text { symptoms }\end{array}$} \\
\hline Weakness & $93(56)$ & $51(31)$ & $43(26)$ & 84 & $42(25)$ & $14(8)$ & 32 & $57(34)$ \\
\hline Tiredness & $87(52)$ & $48(29)$ & $28(17)$ & 59 & $39(23)$ & $7(4)$ & 17 & $35(21)$ \\
\hline General discomfort & $80(48)$ & $27(16)$ & $17(10)$ & 63 & $53(32)$ & $20(12)$ & 38 & $37(22)$ \\
\hline $\begin{array}{l}\text { Changed } \\
\text { appearance }\end{array}$ & $78(47)$ & $40(24)$ & $20(12)$ & 50 & $38(23)$ & $2(1)$ & 4 & $22(13)$ \\
\hline Pain & $72(43)$ & $20(12)$ & $18(11)$ & 92 & $52(31)$ & $7(4)$ & 13 & $25(15)$ \\
\hline Loss of appetite & $62(37)$ & $24(14)$ & $10(6)$ & 43 & $38(23)$ & $15(9)$ & 39 & $25(15)$ \\
\hline $\begin{array}{l}\text { Shortness of } \\
\text { breath }\end{array}$ & $59(35)$ & $17(10)$ & $14(8)$ & 80 & $42(25)$ & $5(3)$ & 12 & $19(11)$ \\
\hline $\begin{array}{l}\text { Impaired } \\
\text { co-ordination }\end{array}$ & $57(34)$ & $17(10)$ & $13(8)$ & 80 & $40(24)$ & $5(3)$ & 13 & $18(11)$ \\
\hline Not sleeping well & $47(28)$ & $12(7)$ & $10(6)$ & 86 & $35(21)$ & $15(9)$ & 43 & $25(15)$ \\
\hline Thirst & $45(27)$ & $18(11)$ & $10(6)$ & 55 & $27(16)$ & $2(1)$ & 6 & $12(7)$ \\
\hline Feeling tensed & $44(26)$ & $12(7)$ & $10(6)$ & 86 & $32(19)$ & $2(1)$ & 5 & $12(7)$ \\
\hline Memory loss & $43(26)$ & $12(7)$ & $7(4)$ & 57 & $32(19)$ & $8(5)$ & 26 & $15(9)$ \\
\hline Impaired sight & $42(25)$ & $5(3)$ & $3(2)$ & 67 & $37(22)$ & $4(2)$ & 9 & $7(4)$ \\
\hline $\begin{array}{l}\text { Impaired mental } \\
\text { clarity }\end{array}$ & $42(25)$ & $10(6)$ & $5(3)$ & 50 & $32(19)$ & $7(4)$ & 21 & $12(7)$ \\
\hline $\begin{array}{l}\text { Loss of } \\
\text { concentration }\end{array}$ & $40(24)$ & $13(8)$ & $12(7)$ & 88 & $27(16)$ & $5(3)$ & 19 & $17(10)$ \\
\hline Coughing & $38(23)$ & $2(1)$ & $2(1)$ & 100 & $36(22)$ & $3(2)$ & 9 & $5(3)$ \\
\hline $\begin{array}{l}\text { Swallow food } \\
\text { impaired }\end{array}$ & $35(21)$ & $7(4)$ & $7(4)$ & 100 & $28(17)$ & $5(3)$ & 18 & $12(7)$ \\
\hline $\begin{array}{l}\text { Smelling } \\
\text { unpleasant }\end{array}$ & $35(21)$ & $8(5)$ & $8(5)$ & 100 & $27(16)$ & $3(3)$ & 19 & $13(8)$ \\
\hline Feeling depressed & $34(20)$ & $3(2)$ & $2(1)$ & 50 & $31(18)$ & $10(6)$ & 33 & $12(7)$ \\
\hline Impaired hearing & $33(20)$ & $8(5)$ & $7(4)$ & 80 & $25(15)$ & $8(4)$ & 27 & $13(8)$ \\
\hline $\begin{array}{l}\text { Incomprehensible } \\
\text { speech }\end{array}$ & $32(19)$ & $14(8)$ & $12(7)$ & 88 & $18(11)$ & $3(2)$ & 18 & $15(9)$ \\
\hline Itch & $32(19)$ & $8(5)$ & $5(3)$ & 60 & $24(14)$ & $2(1)$ & 7 & $7(4)$ \\
\hline Constipation & $30(18)$ & $8(5)$ & $8(5)$ & 100 & $22(13)$ & $4(2)$ & 15 & $12(7)$ \\
\hline Nausea & $28(17)$ & $12(7)$ & $8(5)$ & 71 & $16(10)$ & $5(3)$ & 30 & $13(8)$ \\
\hline Dizziness & $27(16)$ & $5(3)$ & $5(3)$ & 100 & $22(13)$ & 7 (4) & 31 & $12(7)$ \\
\hline
\end{tabular}


Table 2 Relationship between symptom intensity and unbearability for symptoms in the domain of: medical signs and symptoms ( $\mathrm{n}=60)($ Continued)

\begin{tabular}{|c|c|c|c|c|c|c|c|c|}
\hline Vomiting & $27(16)$ & $9(5)$ & $7(4)$ & 80 & $18(11)$ & $13(8)$ & 73 & $20(12)$ \\
\hline Feeling anxious & $27(16)$ & $5(3)$ & $3(2)$ & 67 & $22(13)$ & $4(2)$ & 15 & $7(4)$ \\
\hline $\begin{array}{l}\text { Swallowing fluid } \\
\text { impaired }\end{array}$ & $23(14)$ & $5(3)$ & $5(3)$ & 100 & $18(11)$ & $2(1)$ & 9 & $7(4)$ \\
\hline Hiccups & $22(13)$ & $7(4)$ & $5(3)$ & 75 & $15(9)$ & $5(3)$ & 33 & $10(6)$ \\
\hline Intestinal cramps & $22(13)$ & $5(3)$ & $3(2)$ & 67 & $17(10)$ & $5(3)$ & 30 & $8(5)$ \\
\hline Diarrhea & $20(12)$ & $3(2)$ & $3(2)$ & 100 & $17(10)$ & $4(2)$ & 20 & $7(4)$ \\
\hline $\begin{array}{l}\text { Incontinence of } \\
\text { urine }\end{array}$ & $10(6)$ & $0(0)$ & $0(0)$ & 0 & $10(6)$ & $0(0)$ & 0 & $0(0)$ \\
\hline $\begin{array}{l}\text { Incontinence of } \\
\text { feces }\end{array}$ & $8(5)$ & $2(1)$ & $2(1)$ & 100 & $6(4)$ & $5(3)$ & 75 & $7(4)$ \\
\hline Pressure ulcers & $8(5)$ & $2(1)$ & $2(1)$ & 100 & $6(4)$ & $1(1)$ & 25 & $3(2)$ \\
\hline $\begin{array}{l}\text { Impaired } \\
\text { comprehension of } \\
\text { speech }\end{array}$ & $7(4)$ & $2(1)$ & $2(1)$ & 100 & $5(3)$ & $1(1)$ & 33 & $3(2)$ \\
\hline Paralyzed limbs & $5(3)$ & $2(1)$ & $2(1)$ & 100 & $3(2)$ & $0(0)$ & 0 & $2(1)$ \\
\hline Skin metastasis & $3(2)$ & $3(2)$ & $2(1)$ & 50 & $0(0)$ & $0(0)$ & 0 & $2(1)$ \\
\hline
\end{tabular}

Rounded percentages and absolute numbers; between 0 to 1 missing observations per symptom.

Scoring: 1-not at all; 2-slightly; 3-moderately; 4-seriously; 5-very seriously, hardly can be worse.

Symptom present: intensity scores $2-5$.

Low intensity: scores 1-3; High intensity: scores 4-5; Bearable suffering: scores 1-3; Unbearable suffering: scores 4-5.

*: percentage of interviewed patients followed up until death

n: number of patients. 
Table 3 Relationship between symptom intensity and unbearability in the domains of loss of function, personal aspects, environment, nature and prognosis of disease $(n=60)$

\begin{tabular}{|c|c|c|c|c|c|c|c|c|}
\hline & $\begin{array}{c}\text { Symptom } \\
\text { present \%*(n) }\end{array}$ & $\begin{array}{l}\text { Symptom high } \\
\text { intensity \%* (n) }\end{array}$ & $\begin{array}{l}\text { High intensity and } \\
\text { unbearable } \% *(n)\end{array}$ & $\begin{array}{l}\text { Percentage unbearable } \\
\text { when high intensity \% }\end{array}$ & $\begin{array}{c}\text { symptom low } \\
\text { intensity \%*(n) }\end{array}$ & $\begin{array}{l}\text { Low intensity and } \\
\text { unbearable } \% *(n)\end{array}$ & $\begin{array}{l}\text { Percentage unbearable } \\
\text { when low intensity \% }\end{array}$ & $\begin{array}{c}\text { Symptom } \\
\text { unbearable \%* }\end{array}$ \\
\hline \multicolumn{9}{|l|}{$\begin{array}{l}\text { Domain II: Loss of } \\
\text { function }\end{array}$} \\
\hline $\begin{array}{l}\text { Impaired routine daily } \\
\text { activities }\end{array}$ & $83(50)$ & $58(35)$ & $48(29)$ & 83 & $25(15)$ & $7(4)$ & 27 & $55(33)$ \\
\hline Impaired leisure activities & $82(49)$ & $60(36)$ & $48(29)$ & 81 & $22(13)$ & $2(1)$ & 8 & $50(30)$ \\
\hline $\begin{array}{l}\text { Help needed with } \\
\text { housekeeping }\end{array}$ & $71(42)$ & $54(32)$ & $39(23)$ & 72 & $17(10)$ & $3(2)$ & 20 & $42(25)$ \\
\hline $\begin{array}{l}\text { Help needed with } \\
\text { self-care }\end{array}$ & $60(36)$ & $27(16)$ & $15(9)$ & 56 & $33(20)$ & $7(4)$ & 20 & $22(13)$ \\
\hline Bedridden & $56(33)$ & $32(19)$ & $24(14)$ & 74 & $24(14)$ & $8(5)$ & 36 & $32(19)$ \\
\hline $\begin{array}{l}\text { Impaired working } \\
\text { capacity }\end{array}$ & $17(10)$ & $17(10)$ & $12(7)$ & 70 & $0(0)$ & $0(0)$ & 0 & $12(7)$ \\
\hline $\begin{array}{l}\text { Impaired sexual } \\
\text { functioning }\end{array}$ & $14(8)$ & $12(7)$ & $5(3)$ & 43 & $2(1)$ & $0(0)$ & 0 & $5(3)$ \\
\hline \multicolumn{9}{|l|}{$\begin{array}{l}\text { Domain III: Personal } \\
\text { aspects }\end{array}$} \\
\hline $\begin{array}{l}\text { Feeling dependent on } \\
\text { others }\end{array}$ & $80(48)$ & $50(30)$ & $37(22)$ & 73 & $30(18)$ & $8(5)$ & 28 & $45(27)$ \\
\hline $\begin{array}{l}\text { Not able to do things } \\
\text { you consider important }\end{array}$ & $63(36)$ & $26(15)$ & $23(13)$ & 87 & $37(21)$ & $19(11)$ & 52 & $42(24)$ \\
\hline $\begin{array}{l}\text { Trouble accepting the } \\
\text { present situation }\end{array}$ & $60(36)$ & $30(18)$ & $25(15)$ & 83 & $30(18)$ & $8(5)$ & 28 & $33(20)$ \\
\hline $\begin{array}{l}\text { Feeling a nuisance to } \\
\text { others }\end{array}$ & $38(23)$ & $5(3)$ & $3(2)$ & 67 & $33(20)$ & $10(6)$ & 30 & $13(8)$ \\
\hline $\begin{array}{l}\text { Negative thoughts or } \\
\text { worrying }\end{array}$ & $32(19)$ & $12(7)$ & $8(5)$ & 71 & $20(12)$ & $7(4)$ & 33 & $15(9)$ \\
\hline $\begin{array}{l}\text { Loss of control over your } \\
\text { own life }\end{array}$ & $30(18)$ & $22(13)$ & $20(12)$ & 92 & $8(5)$ & $7(4)$ & 80 & $27(16)$ \\
\hline $\begin{array}{l}\text { Feeling not any longer } \\
\text { being the same person }\end{array}$ & $28(17)$ & $8(5)$ & $8(5)$ & 100 & $20(12)$ & $2(1)$ & 8 & $10(6)$ \\
\hline Hopelessness & $28(17)$ & $7(4)$ & $7(4)$ & 100 & $21(13)$ & $6(4)$ & 31 & $13(8)$ \\
\hline $\begin{array}{l}\text { Experienced little } \\
\text { happiness with family/ } \\
\text { friends }\end{array}$ & $22(13)$ & $5(3)$ & $0(0)$ & 0 & $17(10)$ & $8(5)$ & 50 & $8(5)$ \\
\hline $\begin{array}{l}\text { Feelings of } \\
\text { worthlessness }\end{array}$ & $22(13)$ & $10(6)$ & $8(5)$ & 83 & $12(7)$ & $2(1)$ & 14 & $10(6)$ \\
\hline
\end{tabular}


Table 3 Relationship between symptom intensity and unbearability in the domains of loss of function, personal aspects, environment, nature and prognosis of disease $(n=60)$ (Continued)

\begin{tabular}{|c|c|c|c|c|c|c|c|c|}
\hline $\begin{array}{l}\text { Feeling lonely } \\
\text { (intrapersonal) }\end{array}$ & $20(12)$ & $5(3)$ & $3(2)$ & 67 & $15(9)$ & $7(4)$ & 44 & $10(6)$ \\
\hline $\begin{array}{l}\text { Feeling of no longer } \\
\text { being important to } \\
\text { others }\end{array}$ & $18(11)$ & $5(3)$ & $5(3)$ & 100 & $13(8)$ & $3(2)$ & 25 & $8(5)$ \\
\hline Feeling tired of life & $17(10)$ & $5(3)$ & $5(3)$ & 100 & $12(7)$ & $4(2)$ & 29 & $9(5)$ \\
\hline $\begin{array}{l}\text { Not satisfied with own } \\
\text { self }\end{array}$ & $12(7)$ & $5(3)$ & $5(3)$ & 100 & $7(4)$ & $2(1)$ & 25 & $7(4)$ \\
\hline Feelings of guilt & $12(7)$ & $2(1)$ & $2(1)$ & 100 & $10(6)$ & $3(2)$ & 33 & $5(3)$ \\
\hline $\begin{array}{l}\text { Experienced little success } \\
\text { in life }\end{array}$ & $10(6)$ & $2(1)$ & $0(0)$ & 0 & $8(5)$ & $2(1)$ & 20 & $2(1)$ \\
\hline $\begin{array}{l}\text { Lived a life with little } \\
\text { purpose }\end{array}$ & $8(5)$ & $0(0)$ & $0(0)$ & 0 & $8(5)$ & $2(2)$ & 40 & $3(2)$ \\
\hline \multicolumn{9}{|l|}{$\begin{array}{l}\text { Domain IV: } \\
\text { Environment }\end{array}$} \\
\hline $\begin{array}{l}\text { Relatives consider your } \\
\text { suffering too severe }\end{array}$ & $33(19)$ & $10(6)$ & $9(5)$ & 83 & $23(13)$ & $7(4)$ & 31 & $16(9)$ \\
\hline $\begin{array}{l}\text { Practical loneliness (no } \\
\text { one present for you) }\end{array}$ & $15(9)$ & $8(5)$ & $8(5)$ & 100 & $7(4)$ & $4(2)$ & 50 & $12(7)$ \\
\hline $\begin{array}{l}\text { Insufficient availability of } \\
\text { care }\end{array}$ & $12(7)$ & $2(1)$ & $0(0)$ & 0 & $10(6)$ & $8(5)$ & 83 & $8(5)$ \\
\hline $\begin{array}{l}\text { Unsatisfactory social } \\
\text { contacts }\end{array}$ & $8(5)$ & $2(1)$ & $2(1)$ & 100 & $6(4)$ & $1(1)$ & 25 & $3(2)$ \\
\hline $\begin{array}{l}\text { Insufficient support } \\
\text { (family, relatives) }\end{array}$ & $5(3)$ & $0(0)$ & $0(0)$ & 0 & $5(3)$ & $2(1)$ & 33 & $2(1)$ \\
\hline Shame & $2(1)$ & $0(0)$ & $0(0)$ & 0 & $2(1)$ & $2(1)$ & 100 & $2(1)$ \\
\hline \multicolumn{9}{|l|}{$\begin{array}{l}\text { Domain V: Nature and } \\
\text { prognosis of disease }\end{array}$} \\
\hline Fear of future suffering & $40(24)$ & $15(9)$ & $14(8)$ & 89 & $25(15)$ & $3(2)$ & 13 & $17(10)$ \\
\hline $\begin{array}{l}\text { Fear of future failing } \\
\text { strength to bear } \\
\text { suffering }\end{array}$ & $25(15)$ & $8(5)$ & $8(5)$ & 100 & $17(10)$ & $2(1)$ & 10 & $10(6)$ \\
\hline
\end{tabular}

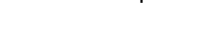


Intensity of symptoms in relationship to unbearability

Analysis of the relationship between intensity of symptoms and consequent unbearability for the most prevalent unbearable symptoms (25 symptoms were unbearable in at least $15 \%$ ) demonstrated that high intensity of symptoms most frequently resulted in unbearable suffering for pain, loss of control over one's life, fear of future suffering, not being able to do important things and not sleeping well (86-92\%). Low intensity of symptoms most frequently resulted in unbearability for loss of control over one's life (80\%), vomiting (73\%), not being able to do important things (52\%), not sleeping well $(43 \%)$ and loss of appetite (39\%).

\section{Intensity of symptoms and unbearable suffering longitudinally}

In 33 patients the SOS-V was administered at least two times. The pre-final interview on average was 123 days before death (SD 47 days). Prevalence of high symptom intensity significantly increased in the period between pre-final and final interview for general discomfort, being bedridden and help needed with self care (Table 4). Prevalence of unbearable suffering significantly increased for weakness.

\section{The nature of suffering: analysis of the qualitative data}

Examples of qualitative answers of patients are provided in Table 5. The process of analysis of the qualitative data is demonstrated in Table 6. Overall unbearable suffering occurred in 28 percent $(n=16)$ of patients interviewed with the SOS-V. No significant difference in age, gender and cancer type occurred for present or absent overall unbearable suffering. The qualitative answers of the patients indicated physical suffering to be responsible for unbearable suffering with a mean of 4,0 in patients with overall unbearable suffering versus 2,1 in patients with overall bearable suffering (Table 7). Loss of meaning was present with a mean of 3,6 in patients with overall unbearable suffering, versus 2,0 in patients without overall unbearable suffering, while for loss of autonomy the mean numbers were 3,1 versus 2,2. All of these differences were statistically significant. Fear of future suffering and worrying were less prevalent overall, yet also went along with a mean higher number in patients with overall unbearable suffering. A remarkable repetitive explanation of unbearability of loss of appetite was the unwanted consequence of further loss of strength, related to not being able to eat.

\section{Discussion}

The present study in end-of-life cancer patients in the home setting and in the care of primary care physicians demonstrated that weakness was the most prevalent physical symptom (93\%), which was unbearable in approximately half of the patients. Pain was present in $72 \%$ of patients and was unbearable in a quarter of patients. A large variety of symptoms was present. If symptoms were of high intensity than unbearability frequently occurred for pain, loss of control, fear of future suffering, not being able to do important things and not sleeping well (86$92 \%)$. If symptoms were of low intensity than unbearability frequently occurred for loss of control, vomiting, not being able to do important things, not sleeping well and loss of appetite (39-80\%). The prevalence of symptom intensity increased significantly between on average four months before death and on average one month before death for general discomfort, being bedridden and help needed with self care; the prevalence of unbearability significantly increased for weakness. Intensity and unbearability of pain were unchanged in the longitudinal follow-up. Evaluation of the qualitative study outcomes demonstrated that physical suffering, loss of autonomy, loss of meaning, fear of future suffering, experiencing to be a burden to others and worrying were significantly more prevalent in patients with overall unbearable suffering. The combined emotional symptoms of psychological distress were higher in patients with overall unbearable suffering.

\section{Strengths and limitations}

The study was realized despite relevant barriers to research of end-of-live cancer patients in primary care (low prevalence of the studied patients, geographical dispersed setting of patients, physicians and researchers, difficulty of recruitment of end-of-life cancer populations for research) [25]. The 51\% recruitment proportion of requested patients is comparable to recruitment proportions in secondary care studies investigating end-oflife cancer patients [10].

The study has limitations. The small sample size inhibited significant statistical analysis of the data of the relationship between intensity of symptoms and unbearability. Unexpected rapid physical deterioration limited the number of interviews shortly before death. The study sample concerns a Western population of patients in a specific setting of care, which limits generalizability.

\section{Comparison to other studies}

No quantitative studies of unbearable suffering were found. Two studies qualitatively investigated unbearable suffering in mixed diagnostic populations (also other diagnoses than cancer) and identified physical, psychosocial and existential themes which contributed to the suffering $[38,39]$. In end-of-life cancer patients in secondary care overall moderate to extreme suffering was reported present in a range of $25 \%-81 \%[11,40,41]$, with physical symptoms, psychological distress and existential concerns contributing to the suffering [11]. The prevalent physical symptoms in this study, such as weakness, tiredness, general discomfort, changed appearance, pain and loss of appetite, are also prevalent in secondary care studies [24]. 
Table 4 Development of intensity and unbearability of symptoms between the pre-final and final interview in patients with at least two interviews ( $\mathbf{n}=33$ )* Symptom in high intensityt

Symptom unbearablet

\begin{tabular}{|c|c|c|c|c|c|c|}
\hline & & & & \\
\hline & Pre-final interview \% (n) & $\begin{array}{l}\text { Final interview } \\
\%(n)\end{array}$ & $\begin{array}{l}\text { Difference pre-final and final } \\
\text { interview } \%(95 \% \mathrm{Cl}) \neq\end{array}$ & $\begin{array}{l}\text { Pre-final interview } \\
\%(n)\end{array}$ & $\begin{array}{l}\text { Final interview } \\
\quad \%(n)\end{array}$ & $\begin{array}{l}\text { Difference pre-final an } \\
\text { interview \% }(95 \% \mathrm{C}\end{array}$ \\
\hline \multicolumn{7}{|l|}{ Domain I: Medical symptoms } \\
\hline Weakness & $36(12)$ & $55(18)$ & $-18(-29$ to 3$)$ & $33(11)$ & $64(21)$ & $-30(-41$ to -6$)$ \\
\hline General discomfort & $9(3)$ & $27(9)$ & $-18(-19$ to -1$)$ & $25(8)$ & $42(14)$ & $-16(-33$ to 9$)$ \\
\hline Tiredness & $39(13)$ & $55(18)$ & $-15(-29$ to 7$)$ & $42(14)$ & $42(14)$ & $0(-16$ to 16$)$ \\
\hline Loss of appetite & $27(9)$ & $18(6)$ & $9(-11$ to 23$)$ & $27(9)$ & $36(12)$ & $-9(-26$ to 13$)$ \\
\hline Pain & $24(8)$ & $21(7)$ & $3(-11$ to 14$)$ & $24(8)$ & $27(9)$ & $-3(-20$ to 16$)$ \\
\hline Not sleeping well & $12(4)$ & $6(2)$ & $6(-10$ to 17$)$ & $9(3)$ & 24(8) & $-15(-26$ to 5$)$ \\
\hline Changed appearance & $30(10)$ & $42(14)$ & $-12(-29$ to 11$)$ & $30(10)$ & $24(8)$ & 6 (-12 to20) \\
\hline Shortness of breath & $6(2)$ & $21(7)$ & $-15(-15$ to 0$)$ & $12(4)$ & $21(7)$ & $-9(-23$ to 11$)$ \\
\hline Vomiting & $3(1)$ & $12(4)$ & $-9(-9$ to 4$)$ & $9(3)$ & 18(6) & $-9(-15$ to 7$)$ \\
\hline Impaired co-ordination & $12(4)$ & $12(4)$ & $0(-14$ to 14$)$ & $24(8)$ & 18(6) & $6(-16$ to 25$)$ \\
\hline Loss of concentration & $21(7)$ & $9(3)$ & $12(-5$ to 18$)$ & $16(5)$ & $18(6)$ & $-3(-18$ to 14$)$ \\
\hline Memory loss & $15(5)$ & $9(3)$ & $6(-7$ to 12$)$ & $19(6)$ & $18(6)$ & $0(-11$ to 11$)$ \\
\hline \multicolumn{7}{|l|}{ Domain II: Loss of function } \\
\hline Impaired routine daily activities & $49(16)$ & $67(22)$ & $-18(-35$ to 7$)$ & $55(18)$ & $61(20)$ & $-6(-27$ to 18$)$ \\
\hline Impaired leisure activities & $49(16)$ & $64(21)$ & $-15(-26$ to 5$)$ & $42(14)$ & $52(17)$ & $-9(-15$ to 6$)$ \\
\hline Help needed with housekeeping & $39(13)$ & $55(18)$ & $-15(-29$ to 7$)$ & $42(14)$ & $39(13)$ & $3(-16$ to 10$)$ \\
\hline Bedridden & $12(4)$ & $36(12)$ & $-24(-30$ to -5$)$ & $18(6)$ & $36(12)$ & $-18(-24$ to 1$)$ \\
\hline Help needed with self-care & $6(2)$ & $27(9)$ & $-21(-27$ to -1$)$ & $15(5)$ & $30(10)$ & $-15(-25$ to 5$)$ \\
\hline \multicolumn{7}{|l|}{ Domain III: Personal aspects } \\
\hline Not able to do important things & $39(13)$ & $31(10)$ & $9(-11$ to 24$)$ & $39(13)$ & $55(18)$ & $-15(-26$ to 5$)$ \\
\hline Feeling dependant on others & $33(11)$ & $55(18)$ & $-21(-32$ to 1$)$ & $39(13)$ & $52(17)$ & $-11(-23$ to 8$)$ \\
\hline Trouble accepting situation & $21(7)$ & $36(12)$ & $-15(-26$ to 5$)$ & $27(9)$ & 39(13) & $-12(-26$ to 9$)$ \\
\hline Loss of control over own life & $9(3)$ & $21(7)$ & $-12(-23$ to 7$)$ & $16(5)$ & $30(10)$ & $-13(-23$ to 8$)$ \\
\hline Negative thoughts or worrying & $12(4)$ & $16(5)$ & $-3(-14$ to 11$)$ & $18(6)$ & $18(6)$ & $0(-17$ to 17$)$ \\
\hline
\end{tabular}


Table 4 Development of intensity and unbearability of symptoms between the pre-final and final interview in patients with at least two interviews ( $\mathrm{n}=33$ )* (Continued)

Domain IV: Environment

Relatives: suffering to severe

9(3)

$0^{* *}$

$12(4)$

15(5)

$-3(-9$ to 7$)$

Domain V: Nature and prognosis of disease

Fear of future suffering

12(4)

$-3(-14$ to 11$)$

13 (4)

12(4)

0 (-11 to 11$)$

Overall unbearable suffering

$13(4)$

33(11)

$-20(-27$ to 1$)$

* Selection of most frequent unbearable symptoms: symptoms which were unbearable (score 4 or 5 ) in at least 15\% (9 patients) in the last interview for all patients with at least one interview; between 0-2 missing observations per symptom; three missing observations for overall unbearable suffering.

High intensity: score 4 or 5 for intensity according to SOS-V; unbearable: score 4 or 5 for unbearability according to SOS-V.

₹ $95 \%$ confidence intervals calculated taking into account that results for pre-final and final interview are paired per patient; significant outcomes ( 0 outside of confidence interval) presented in bold.

** calculation of $95 \% \mathrm{Cl}$ not possible because scores are identical between pre-final and final interview for each patient. 


\section{Table 5 Personal descriptions of unbearable suffering by patients with high scores (score 4 or 5 ) on the SOS-V in the} ultimate interview

\begin{tabular}{|c|c|}
\hline General discomfort: & You just feel miserable, it feels like a sort of flue, you don't fancy doing anything, you only want to lie in bed \\
\hline Tired: & $\begin{array}{l}\text { I hardly can do anything, it is nearly impossible to explain it in words, I never imagined a person could be so } \\
\text { tired }\end{array}$ \\
\hline Weakness: & $\begin{array}{l}\text { My right leg is to weakened, it is not safe to stand and so for weeks I lie in my bed all the time and only come out } \\
\text { for the latrine chair }\end{array}$ \\
\hline Not sleeping well: & $\begin{array}{l}\text { There is the noise at night on the streets, ambulances passing by, and this screaming neighbor woman, who } \\
\text { keeps the whole neighborhood awake }\end{array}$ \\
\hline Pain: & I have pain all day, it occupies my mind, there is little distraction \\
\hline Loss of appetite: & I can hardly any more enjoy the taste of food, I long for the flavor of a fine stew \\
\hline Thirst: & My mouth is dry, I need to drink, but this makes me nauseous \\
\hline Smelling unpleasant: & I hate this urine smell \\
\hline Changed appearance: & I used to be vain, now I have become so thin, I find it ugly looking at my neck \\
\hline Impaired mental clarity: & $\begin{array}{l}\text { I think about something, and then it's gone, I find that stupid, for instance when I am one my way to fetch } \\
\text { something }\end{array}$ \\
\hline Concentration loss: & My mind loses its way, I find this unpleasant \\
\hline Memory loss: & I used to remember all by mind, because I am illiterate \\
\hline Feel tense: & I try to control it, for the children \\
\hline Feel depressed: & This depressed mood in itself is unpleasant; at the same time it grows, because my daughter is doing less well \\
\hline Feel anxious: & I feel afraid for what will come and worry about how things will go on for my wife \\
\hline Shortness of breath: & Even with only slight activity I have a sort of hyperventilation, which makes me anxious \\
\hline Coughing: & When in public, than this phlegm comes out in my handkerchief, it's very annoying \\
\hline Obstruction to swallow food: & I need to feed myself to prevent becoming even more weakened, but the passage of food is deranged \\
\hline Obstruction to swallow fluid: & I swallow, but it doesn't pass, it makes me retch \\
\hline Nausea & I am nauseous continuously, I feel completely fed up with it \\
\hline Constipation: & It hurts and is strenuous \\
\hline Diarrhea: & You are dining out in a hotel and then you continuously need to go to the toilet \\
\hline Intestinal cramps: & These cramps are painful, it is very unpleasant \\
\hline Incontinence of urine: & X (no high scores in ultimate interview) \\
\hline Incontinence of feces: & It is filthy \\
\hline Hiccups: & It comes sudden and unexpected, it makes me feel uncivilized and ashamed \\
\hline Pressure ulcers: & It is annoying \\
\hline Itch: & You keep on scratching \\
\hline Skin metastasis: & In my neck, after radiotherapy it turned yellow, with an unpleasant look, it smells \\
\hline Paralyzed limbs: & I can't do anything, my left leg is paralyzed and my arm is forceless \\
\hline Impaired coordination: & These unpredictable cramps and shaking of an arm or a leg, I cannot stop it \\
\hline Incomprehensible speech: & I cannot communicate by telephone, people don't understand what I am saying \\
\hline $\begin{array}{l}\text { Impaired comprehension of } \\
\text { speech: }\end{array}$ & It makes me feel stupid \\
\hline Dizziness: & $\begin{array}{l}\text { Sometimes it is frightening, one time it happened when my alarm-button was out of reach and it took a whole } \\
\text { long time before anybody entered and took notice }\end{array}$ \\
\hline Impaired sight: & It annoys me so much, it is caused by the medication \\
\hline Impaired hearing: & If some people talk at the same time I cannot differentiate what is being said \\
\hline Impaired working capacity: & I am already counted out in society \\
\hline $\begin{array}{l}\text { paired in routine daily } \\
\text { tivities. }\end{array}$ & I am not the crying type, but this week I suddenly started crying \\
\hline
\end{tabular}




\section{Table 5 Personal descriptions of unbearable suffering by patients with high scores (score 4 or 5 ) on the SOS-V in the ultimate interview (Continued)}

Impaired leisure activities:

Need help with housekeeping:

Need help with self-care:

Pedridden:

Restricted sexual functioning:

Not satisfied with own self:

Lived a life with little purpose:

Experienced little success in life:

Little happiness with family/

close ones:

Trouble accepting situation:

Negative thoughts or worrying:

Feelings of guilt:

Feel worthless:

Feel lonely:

Feel hopeless:

No longer feel the same person:

Feel tired of life:

Feel dependant of others:

Feeling loss of control of life:

Feeling a nuisance to others:

Feel unimportant to others:

Impossible to do important things:

Not supported sufficiently by close ones:

Lonely (important people absent):

Feelings of shame:

Relatives consider your suffering severe:

Unsatisfactory contact with close ones:

Insufficient availability of care:

Fear of future suffering:

Fear losing strength to bear the suffering:

Personal additions of missing aspects:
I used to go out, make bus trips, I miss it, but absolutely can't do it anymore. And I can't any more receive people at my home, I am to exhausted

Being young and not capable to function independently, it feels so unnatural

I don't want these young maidens of the home care service, it makes me feel ashamed

More and more you are drawn to that bed, it makes you realize you are deteriorating

Widower: I feel rejected by my present partner, there is no intimacy, it is so cold

I just left my wife, she had done nothing wrong, life than takes a course, leaving impossible to restore the situation With my first wife everything was fine, the last years I miss love and tenderness

I would have liked to be at a somewhat higher level in society, for instance I would have liked to study, I would do it differently if I could do it again

I would have preferred things to be different, I haven't seen my children for 18 years

I can no longer play Chopin, or make a drawing

I would have liked to do things differently, at night it appears in my dreams

I feel guilt I wanted to divorce from my wife the other year, she is the one who makes I am still living now, she does everything for me

There is no more appreciation, people talk about you and not with you

One has cancer, it is not contagious, but people pass by less frequently

This is not what I want

Is this the same body? Yet I have to manage with it, which causes me trouble

I prefer it to be over as soon as possible, I used to be very active and independent and now I am totally passive and dependant

Ones individuality is lost, one has no more privacy

Tears in the eyes, gives no answer

In relation to being so dependant I now easily tend to think "Oh, just leave it"

My daughter, she is very sick and I can't do anything for her

I used to daily visit my wife in a nursing-home, I can't do it any longer

The physical support is O.K., but there is emotional shortage

I have one son, he does not visit me

I have these outburst directed at my own person, which I find alarming, than this tic of my jaw appears and I wonder whether I can appear this way in church

It makes it difficult to start a conversation

They don't keep stand up to their promises, for instance my daughter promises to visit me next week, I look forward to see her and then she shows up 1,5 years later

I find the home care miserable

I feel short of breath, I am afraid to suffocate

To die, would it be painful?

The hospice refused me last week, they considered me too good and advised a nursing home

\section{Interpretation}

Palliative home care has to meet the challenge of reducing unbearable suffering in end-of-life cancer patients. Between countries substantial differences in organization of palliative home care exist [2]. Palliative home care is provided in various models, such as general practitioner delivered palliative care $[4,42]$ and home-based hospice care $[43,44]$. The services provided within these models are not 
Table 6 Symptom, description of what makes the symptom unbearable and rated category; examples

\begin{tabular}{|c|c|c|}
\hline Symptom & Description of unbearability by patient & Rated category \\
\hline Tired? & $\begin{array}{l}\text { I hardly can do anything, it is nearly impossible to explain it in words. } \\
\text { I never imagined a person could be so tired }\end{array}$ & Physical \\
\hline Lonely (important people absent)? & I have one son, he does not visit me & Loss of meaning \\
\hline Feel dependant on others? & $\begin{array}{l}\text { I used to be very independent, and do all myself. } \\
\text { Now I need to ask for everything, or wait. }\end{array}$ & Loss of autonomy \\
\hline Hiccups? & It comes sudden and unexpected, it makes me feel uncivilized and ashamed & Loss of dignity \\
\hline Feel to be a burden to others? & My husband, he needs to care for me continuously & Burden to others \\
\hline Restricted sexual functioning? & It is gone, it is in pieces, not only for myself, but also for my wife & Loss of sexual role \\
\hline Fear of future suffering? & I am in fear of suffering pain, that the pain will be unbearable & Fear of suffering \\
\hline Nausea? & $\begin{array}{l}\text { I feel panic. Am I going to vomit? Is it going to be difficult to breathe? } \\
\text { Is it going to happen when I am eating? }\end{array}$ & Anxiety \\
\hline Fear of future suffering? & I am frightened to suffocate & Death anxiety \\
\hline Feel depressed? & $\begin{array}{l}\text { This depressed mood in itself is unpleasant, at the same time it grows, } \\
\text { because my daughter is doing less well }\end{array}$ & Depressive thoughts \\
\hline Negative thoughts, worrying? & $\begin{array}{l}\text { It haunts my mind all day: dissemination of cancer to my liver, } 2 \text { to } 3 \text { months to live. } \\
\text { An operation? Other possibilities? }\end{array}$ & Worrying \\
\hline Feel tensed? & To be able to be more relaxed would help me; now it makes me lose much energy & Feeling tensed \\
\hline Hopelessness? & To take up a piece of paper , I can't manage it, I cannot stand it & Hopelessness \\
\hline Trouble accepting present situation? & The fact that it is as it is, to look it in the face. It is over, I am just waiting & Pointlessness \\
\hline
\end{tabular}

Table 7 Categories of suffering for patients who did or did not experience overall unbearable suffering (results from coding of open questions on why aspects of the SOS-V were unbearable)

\begin{tabular}{|c|c|c|c|c|c|}
\hline \multirow[b]{2}{*}{$\begin{array}{l}\text { Categories of } \\
\text { suffering }\end{array}$} & \multicolumn{2}{|c|}{ Overall unbearable suffering $(n=16)$} & \multicolumn{2}{|c|}{ Overall bearable suffering $(n=41)$} & \multirow[b]{2}{*}{$\begin{array}{l}p \text {-value of t-test } \\
\text { for means }\end{array}$} \\
\hline & $\begin{array}{l}\text { Category present in } \\
\text { patients } \%(n)\end{array}$ & $\begin{array}{c}\text { Mean number in which } \\
\text { category is present per } \\
\text { patient Mean (stdev) }\end{array}$ & $\begin{array}{l}\text { Category present in } \\
\text { patients } \%(n)\end{array}$ & $\begin{array}{c}\text { Mean number in which } \\
\text { category is present per } \\
\text { patient Mean (stdev) }\end{array}$ & \\
\hline Physical suffering & $100(16)$ & $4.0(2.1)$ & $61(25)$ & $2.1(2.4)$ & 0.008 \\
\hline Loss of meaning & $88(14)$ & $3.6(3.3)$ & $63(26)$ & $2.0(2.1)$ & 0.027 \\
\hline Loss of autonomy & $88(14)$ & $3.1(2.2)$ & $44(18)$ & $2.2(1.6)$ & 0.003 \\
\hline Loss of dignity & $56(9)$ & $1.1(1.5)$ & $32(13)$ & $0,5(0.9)$ & 0.064 \\
\hline $\begin{array}{l}\text { Experience to be a } \\
\text { burden to others }\end{array}$ & $56(9)$ & $0.7(0.7)$ & $17(7)$ & $0.2(0.5)$ & 0.025 \\
\hline Loss of sexual role & $6(1)$ & $0.1(0.3)$ & $2(1)$ & $0.02(0.2)$ & 0.491 \\
\hline $\begin{array}{l}\text { Fear of future } \\
\text { suffering }\end{array}$ & $44(7)$ & $0.8(0.9)$ & $5(2)$ & $0.04(0.2)$ & 0.009 \\
\hline Anxiety & $31(5)$ & $0.6(1.2)$ & $7(3)$ & $0.1(1.3)$ & 0.089 \\
\hline Death anxiety & $6(1)$ & $0.1(0.5)$ & $0(0)$ & $0.0(0.0$ & 0.333 \\
\hline Depressive thoughts & $19(3)$ & $0.2(0.4)$ & $2(1)$ & $0.02(0.2)$ & 0.134 \\
\hline Worrying & $44(7)$ & $0.5(0.6)$ & $5(2)$ & $0.1(0.3)$ & 0.020 \\
\hline Feeling tensed & $13(2)$ & $0.1(0.3)$ & $5(2)$ & $0.05(0.2)$ & 0.417 \\
\hline Hopelessness & $19(3)$ & $0.2(0.4)$ & $2(1)$ & $0.02(0.2)$ & 0.134 \\
\hline Pointlessness & $13(2)$ & $0.4(1.1)$ & $2(1)$ & $0.4(0.5)$ & 0.299 \\
\hline $\begin{array}{l}\text { Emotional } \\
\text { symptoms }\end{array}$ & $75(12)$ & $2.1(2.6)$ & $20(8)$ & $0.3(0.8)$ & 0.014 \\
\hline
\end{tabular}

$\%$ : percentage of patients.

$\mathrm{n}$ : number of patients.

stdev: standard deviation.

Emotional symptoms of psychological distress: anxiety, death anxiety, depressive thoughts, worrying, feeling tensed, hopelessness and pointlessness. 
standard [45] and few studies have assessed the intensity of palliative home care delivery in the last months of a patient's life [46]. Transitions from oncology care to palliative care may influence patient well-being [47-49]. Palliative care is an accomplished formal medical specialization in some countries [50,51], providing possibility of structural integration of specialist palliative care within various health care settings, and providing possibility of educational fellowship rotations for various medical health specialties. In the Netherlands palliative care is not a specialty. Psycho-oncologic interventions provided by mental health professionals have been tested in various cancer populations [35,52-57]. Yet, for bed-ridden end-oflife cancer patients at home the contributions of psychooncologic interventions hardly are found applied or tested.

In the Netherlands legalized EPAS, with the compulsory criterion of unbearable suffering, most frequently concerns end-of-life cancer patients in primary care. It therefore appears that unbearable suffering prevalently is experienced in end-of-life cancer patients cared for in primary care. However, in the absence of studies it must be acknowledged that it is unknown which part of unbearably suffering patients die as a consequence of EPAS, nor is it clear which are the decisive steps from unbearable suffering to EPAS. Some specific situations in primary palliative care may influence suffering. Patients referred back from oncology care to home care, after hearing that no more treatment remains to slow down progress of cancer, may be demoralized [31]. Preference of cancer patients to die at home may inhibit interventions which require the setting of secondary care. In primary care selection occurs of patients with an explicit request for EPAS as a consequence of referrals by secondary care physicians of patients with a request for EPAS to their primary care physician. The frequency of these informal referrals is unknown. Mechanisms of transference and counter-transference about coping with suffering may be more prominent in primary care as a consequence of strong patient-physician relationships [58-61]. Further dynamics of care alter once a decision is made to proceed in a process towards EPAS [20,62].

Our study demonstrates many physical and psychosocial symptoms in end-of-life cancer patients cared for in primary care. Weakness was the most prevalent unbearable symptom. End-of-life cancer patients, in the home setting more than in hospital, may be confronted with loss of social role and autonomous functioning due to weakness. Pain, a potent cause of suffering [63,64], was unbearable in a relevant proportion of patients. The qualitative evaluation of the study indicates that core qualities of suffering were significantly more prevalent in patients who experienced overall suffering to be unbearable.

The results of our study underscore the need of adequate symptom control combined with psycho-oncologic interventions. Adequate control of adverse physical symptoms [65] makes it easier to address patients' concerns about their families, about their own psychological integrity, and about meaning in their lives [30]. Existential aspects of suffering are addressed by psycho-oncologic interventions directed at meaning $[29,53,57]$ and dignity $[35,54]$. Other types of interventions address acceptance and reactive emotional states $[55,56]$. Strength provided by the patient-physician relationship is another quality which may provide recovery from suffering $[29,59,66,67]$. The present study also shows that high intensity of symptoms does not necessarily indicate suffering, while low intensity of symptoms indeed may be unbearable.

We conclude that end-of-life cancer patients in primary care must cope with physical symptoms, loss of meaning, the emotional impact of suffering and the poor prognosis. Primary care physicians, as part of education in palliative care, therefore should be trained in understanding and diagnosing the multiple dimensions of suffering. The use of a framework of domains of suffering provides structure in assessment of suffering. It is not enough to assess the suffering: when meeting patients and taking their history, clinicians should keep a mental $\log$ of the issues that can be improved [47].

Further studies, as to improve understanding and develop interventions, should address unbearable suffering in various settings of care and investigate which are decisive steps from unbearable suffering to EPAS.

\section{Ethical approval}

The study was approved by the Medical Ethics Committee at the VU University Medical Center (METC VUmc No. 2002/79).

\section{Additional file}

Additional file 1: State-Of-Suffering-V.

\section{Competing interest}

The authors declare that they have no competing interest.

\section{Authors' contributions}

CR had the initial idea for this study and wrote the initial research proposal. AK, GW and BOP commented on and contributed to the final research proposal. CR and BOP analyzed the data. CR wrote the paper, which was critically read by all the authors. All contributors had access to all the data and can take responsibility for the integrity of the data and the accuracy of the data analysis. All authors read and approved the final manuscript.

Acknowledgement

We thank all the patients and the GPs, who made possible the realization of this study. We thank Janneke Goedhart, who was the invaluable study coordinator of this research and administered most interviews. We thank Narayanswami Sreeram for linguistic revision. We thank Jos de Keijser for categorization and co-interpretation of the qualitative data. 


\section{Funding}

The study was supported by the Netherlands Organization for Scientific Research (NWO); the Aspasia program. The funding source had no role in any aspect of the study in this paper.

\section{Author details}

${ }^{1}$ Department of Public and Occupational Health, Expertise Center for Palliative Care, VU University Medical Center, EMGO+Institute, van der Boechorststraat 7, 1081 BT Amsterdam, The Netherlands. ${ }^{2}$ Department of Clinical Psychology, VU University, EMGO+Institute, van der Boechorststraat 1, 1081 BT Amsterdam, The Netherlands. ${ }^{3}$ Primary Care Center De Greev, Grevelingenstraat 10, 3522 PR Utrecht, The Netherlands.

Received: 17 May 2013 Accepted: 18 December 2013

Published: 28 December 2013

\section{References}

1. Higginson IJ, Sen-Gupta GJA: Place of care in advanced cancer: a qualitative systematic literature review of patient preferences. J Palliat Med 2000, 3:287-300

2. Bruera E, Sweeney C, Russell N, Willey JS, Palmer JL: Place of death of Houston area residents with cancer over a two-year period. J Pain Symptom Manage 2003, 26:637-643.

3. Cohen J, Houttekier D, Onwuteaka-Philipsen B, Miccenesi G, Addington-Ha J, Kaasa S, Bilsen J, Deliens L: Which patients with cancer die at home? A study of six European countries using death certificate data. J Clin Oncol 2010, 28:2267-2273

4. Schneider N, Mitchell GK, Murray SA: Palliative care in urgent need of recognition and development in general practice: the example of Germany. BMC Fam Pract 2010, 11:66.

5. Smith GF, Toonen TR: Primary care of the patient with cancer. Am Fam Physician 2007, 75:1207-1214

6. Groot MM, Vernooij-Dassen MJFJ, Crul BJP, Grol RPTM: General practitioners (GPs) and palliative care: perceived tasks and barriers in daily practice. Pall Med 2005, 19:111-118.

7. Kuin A, Courtens AM, Deliens L, Vernooij-Dassen MJFJ, van Zuylen L, van der Linden B, van der Wal G: Palliative care consultation in the Netherlands: a nationwide evaluation study. J Pain Symptom Manage 2004, 27:53-60.

8. Jordhoy MS, Fayers P, Saltnes T, Ahlner-Elmqvist M, Jannert M, Kaasa S: A palliative-care intervention and death at home: a cluster randomized trial. Lancet 2000, 356:888-893.

9. Institute for Health Services Research: Nivel: Figures from the registration of general practitioners; estimates. Netherlands (In Dutch); 2008.

10. Ruijs CDM, Kerkhof AJFM, van der Wal G, Onwuteaka-Philipsen BD: The broad spectrum of unbearable suffering in end-of-life cancer patients. A cross-sectional primary care study in the Netherlands. BMC Palliative Care 2012, 11:12

11. Wilson KG, Chochinov HM, McPherson CJ, LeMay K, Allard P, Chary S, Gagnon PR, Macmillan K, De Luca M, O'Shea F, Kuhl D, Fainsinger RL: Suffering with advanced cancer. J Clin Oncol 2007, 25:1691-1697.

12. Breitbart W, Rosenfeld B, Pessin H, Kaim M, Funesti-Esch J, Galietta M, Nelson CJ, Brescia R: Depression, hopelessness, and desire for hastened death in terminally ill cancer patients with cancer. JAMA 2000, 284:2907-2911.

13. Chochinov HM, Wilson KG, Enns M, Mowchun N, Lander S, Levitt M, Clinch J]: Desire for death in the terminally ill. Am J Psychiatry 1995, 152:1 185-1191.

14. Wilson KG, Chochinov HM, McPherson CJ, Skirko MG, Allard P. Chary S, Gagnon PR, Macmillan K, De Luca M, O'Shea F, Kuhl D, Fainsinger RL, Karam AM, Clinch Jj: Desire for euthanasia or physician-assisted suicide in palliative cancer care. Health Psychol 2007, 26:314-323.

15. Hudson LP, Kristjanson LJ, Ashby M, Kelly B, Schofield P. Hudson R, Aranda $\mathrm{S}$, O'Connor M, Street A: Desire for hastened death in patients with advanced disease and the evidence base of clinical guidelines: a systematic review. Palliat Med 2006, 20:693-701.

16. Kelly B, Burnett P, Pelusi D, Badger S, Varghese F, Robertson M: Terminally ill cancer patients wish to hasten death. Palliat Med 2002, 16:339-345.

17. Rietjens JAC, van der Maas PJ, Onwuteaka-Philipsen BD, van Delden JJM, van der Heide A: Two decades of research on euthanasia from the Netherlands. What have we learnt and what questions remain? I Bioeth Ing 2009, 6:271-283.
18. Steck N, Egger M, Maessen M, Reisch T, Zwahlen M: Euthanasia and assisted suicide in selected European countries and US States. Systematic literature review. Med Care 2013, 51:938-944

19. Onwuteaka-Philipsen BD, Brinkman-Stoppelenburg A, Penning C, de JongKrul GJF, van Delden JJM, van der Heide A: Trends in end-of-life practices before and after the enactment of the euthanasia law in the Netherlands from 1990 to 2010: a repeated cross-sectional survey. Lancet 2012. 380:908-915.

20. Harris D, Richard B, Khanna P: Assisted dying: the ongoing debate. Postgrad Med J 2006, 82:479-482

21. Pasterfield D, Wilkinson C, Finlay IG, Neal RD, Hulbert NJ: GPs' views on changing the law on physician-assisted suicide and euthanasia, and willingness to prescribe or inject lethal drugs: a survey from Wales. Br J Gen Pract 2006, 56:450-452.

22. Kelly B, Burnett P, Badger S, Pelusi D, Varghese FT, Robertson M: Doctors and their patients: a context for understanding the wish to hasten death. Psycho-Oncol 2003, 12:375-384.

23. Dutch Cancer Registration managed by IKNL. http://www.iknl.nl/sterfte over kanker [In Dutch]

24. Teunissen SCCM, Wesker W, Kruitwagen C, de Haes HCJM, Voest EE, de Graeff A: Symptom prevalence in patients with incurable cancer: a systematic review. J Pain Symptom Manage 2007, 34:94-104.

25. Ruiis CDM, Goedhart J, Kerkhof AJFM, van der Wal G, Onwuteaka-Philipsen BD: Recruiting end-of-life cancer patients in general practice in the Netherlands for a study on suffering and euthanasia requests. Fam Pract 2011, 28:689-695.

26. Ruijs CDM, Kerkhof AJFM, van der Wal G, Onwuteaka-Philipsen BD: Depression and explicit requests for euthanasia in end-of-life cancer patients in primary care in the Netherlands: a longitudinal, prospective study. Fam Pract 2011, 28:393-399.

27. Kaasa S, Loge JH: Quality-of-life assessment in palliative care. Lancet Oncol 2002, 3:175-182

28. Ruiis CDM, Onwuteaka-Philipsen BD, van der Wal G, Kerkhof AJFM: Unbearability of suffering at the end-of-life: the development of a new measuring device, the SOS-V. BMC Palliative Care 2009, 8:16

29. Cassel EJ: The nature of suffering and the goals of medicine. $N$ Engl J Med 1982, 306:639-645.

30. Block SD: Psychological considerations, growth, and transcendence at the end of life. The art of the possible. JAMA 2001, 285:2898-2905.

31. Kissane DW, Clarke DM: Demoralization syndrome-a relevant psychiatric diagnosis for palliative care. J Palliat Care 2001, 17:12-21.

32. Homsi J, Walsh D, Rivera N, Rybicki LA, Nelson KA, LeGrand SB, Davis M, Naughton M, Grozdjan D, Pham H: Symptom evaluation in palliative medicine: patient report vs systematic assessment. Support Care Cancer 2006, 14:444-453.

33. Cleeland CS: Symptom burden: multiple symptoms and their impact as patient-reported outcomes. J Natl Cancer Inst Monogr 2007, 37:16-21.

34. Sachs E, Kolva E, Pessin H, Rosenfeld B, Breitbart W: On sinking and swimming: the dialectic of hope, hopelessness, and acceptance in terminal cancer. Am J Hosp Palliat Care 2012, 30:121-127.

35. Kissane DW: The relief of existential suffering. Arch Intern Med 2012, 172:1501-1505.

36. McClain CS, Rosenfeld B, Breitbart W: Effects of spiritual well-being on endof-life despair in terminally-ill cancer patients. Lancet 2003, 361:1603-1607.

37. Pessin H, Rosenfield B, Breitbart W: Assessing psychological distress near the end of life. Am Behav Sci 2002, 46:357-372.

38. Pasman HRW, Rurup ML, Willems DL, Onwuteaka-Philipsen BD: Concept of unbearable suffering in context of ungranted requests for euthanasia: qualitative interviews with patients and physicians. BMJ 2009, 339:b4362.

39. Dees MK, Vernooij-Dassen MJ, Dekkers WJ, Vissers KC, van Weel C: "Unbearable suffering": a qualitative study on the perspectives of patients who request assistance in dying. J Med Ethics 2011, 37:727-734.

40. Kuuppelomäki M, Lauri S: Cancer patients' reported experiences of suffering. Cancer Nurs 1998, 21:364-369.

41. Benedict S: The suffering associated with lung cancer. Cancer Nurs 1989, 12:34-40.

42. Mitchell GK: How well do general practitioners deliver palliative care? A systematic review. Palliat Med 2002, 16:457-464

43. Gomes B, Calanzani N, Gysels M, Hall S, Higginson IJ: Heterogeneity and changes in preferences for dying at home: a systematic review. BMC Palliative Care 2013, 12:7. 
44. Jack BA, Baldry CR, Groves KE, Whelan A, Sephton J, Gaunt K: Supporting home care for the dying: an evaluation of healthcare professionals' perspectives of an individually tailored hospice at home service. J Clin Nurs 2013, 22:2778-2786.

45. Labson MC, Sacco MM, Weissman DE, Gornet B, Stuart B: Innovative models of home-based palliative care. Clev Clin J Med 2013, $80 \mathrm{E}$ (supplement I):S30-S35.

46. Alonso-Babarro A, Bruera E, Varela-Cerdeira M, Boya-Cristia MJ, Madero R, Torres-Vigil I, De Castro J, González-Barón M: Can this patient be discharged home? Factors associated with at-home death among patients with cancer. J Clin Oncol 2011, 29:1159-1167.

47. Finlay IG, Pease N: Palliative medicine: communication to promote life near the end of life. In Handbook of communication in oncology and palliative care. Edited by Kissane DW, Bultz BD, Butow PM, Finlay IG. Oxford: Oxford University Press; 2011:491-502.

48. Fleming MO, Trahan Haney $\mathrm{T}$ : Improving patient outcomes with better care transitions: the role for home health. Clev Clin J Med 2013, $80 \mathrm{E}$ (supplement I):S2-S6.

49. Hui D, Nooruddin Z, Didwaniya N, Dev R, De La Cruz M, Kim SH, Kwon JH, Hutchins R, Liem C, Bruera E: Concepts and definitions for "actively dying", "end of live", "terminally ill", "terminally care" and "transition of care": a systematic review. J Pain Symptom Manage 2013. doi:10.1016/ jpainsymman.2013.02.021 [E pub ahead of print].

50. Ferris FD, Bruera E, Cherny N, Cummings C, Currow D, Dudgeon D, JanJan $\mathrm{N}$, Strasser F, von Gunten CF, von Roenn JH: Palliative cancer care a decade later: accomplishments, the need, next steps-from the American society of clinical oncology. J Clin Oncol 2009, 27:3052-3058.

51. Bruera $E_{1}$ Hui D: Palliative care research: lessons learned by our team over the last 25 years. Palliat Med 2013, 27:939-951.

52. LeMay K, Wilson KG: Treatment of existential distress in life threatening illness: a review of manualized interventions. Clin Psychol Rev 2008, 28:472-493.

53. Breitbart W, Poppito S, Rosenfeld B, Vickers AJ, Li Y, Abbey J, Olden M, Pessin H, Lichtenthal W, Sjoberg D, Cassileth BR: Pilot randomized controlled trial of individual meaning-centered psychotherapy for patients with advanced cancer. J Clin Oncol 2012, 30:1304-1309.

54. Chochinov HM, Kristjanson $\amalg$, Breitbart W, McClement S, Hack TF, Hassard T, Harlos M: Effect of dignity therapy on distress and end-of-life experience in terminally ill patients: a randomised controlled trial. Lancet Oncol 2011, 12:753-762.

55. Hoffman CJ, Ersser SJ, Hopkinson JB, Nicholls PG, Harrington JE, Thomas PW: Effectiveness of mindfulness-based stress reduction in mood, breast- and endocrine-related quality of life, and well-being in Stage 0 to III breast cancer: a randomized, controlled trial. J Clin Oncol 2012, 30:1335-1342.

56. Shennan C, Payne S, Fenlon D: What is the evidence for use of mindfulness-based interventions in cancer care? A review. Psychooncology 2011, 20:681-697.

57. Henry M, Cohen SR, Lee V, Sauthier P, Provencher D, Drouin P, Gauthier $P$, Gotlieb W, Lau S, Drummond N, Gilbert L, Stanimir G, Sturgeon J, Chasen M, Mitchell J, Huang LN, Ferland MK, Mayo N: Meaning-making intervention (MMi) appears to increase meaning in life in advanced ovarian cancer: a randomized controlled pilot study. Psychooncology 2010, 19:1340-1347.

58. Pascoe SW, Neal RD, Allgar VL, Selby PJ, Wright EP: Psychosocial care for cancer patients in primary care? Recognition of opportunities for cancer care. Fam Pract 2004, 21:437-442.

59. Hamilton NG, Hamilton CA: Competing paradigms of response to assisted suicide requests in Oregon. Am J Psychiatry 2005, 162:1060-1604.

60. Lloyd-Williams M, Reeve J, Kissane D: Distress in palliative care patients: developing patient-centred approaches to clinical management. Eur J Cancer 2008, 44:1133-1138.

61. Hoglend P, Bogwald KP, Amlo S, Marble A, Ulberg R, Sjaastad MC, Sorbye O, Heyerdahl O, Johansson P: Transference interpretations in dynamic psychotherapy: do they really yield sustained effects? Am J Psychiatry 2008, 165:763-771.

62. Kenny NP: Responding to requests for euthanasia and physician-assisted suicide. In Palliative care. Edited by Emanuel LL, Librach SL. U.S.A: Elsevier Saunders; 2011:284-299.

63. Mori M, Elsayem A, Reddy SK, Bruera E, Fadul NA: Unrelieved pain and suffering in patients with advanced cancer. Am J Hosp Palliat Care 2012, 29:236-240
64. Emanuel EJ: Depression, euthanasia and improving end-of-life care. J Clin Oncol 2005, 23:6456-6458.

65. Shoemaker LK, Estfan B, Induru R, Walsh TD: Symptom management: an important part of cancer care. Clev Clin J Med 2011, 78:25-34.

66. Tan A, Zimmermann C, Rodin G: Interpersonal processes in palliative care: an attachment perspective on the patient-clinician relationship. Palliat Med 2005, 19:143-150.

67. Houston WR: The doctor himself as a therapeutic agent. Ann Intern Med 1938, 11:1416-1425.

doi:10.1186/1471-2296-14-201

Cite this article as: Ruijs et al:: Symptoms, unbearability and the nature of suffering in terminal cancer patients dying at home: a prospective primary care study. BMC Family Practice 2013 14:201.

\section{Submit your next manuscript to BioMed Central and take full advantage of:}

- Convenient online submission

- Thorough peer review

- No space constraints or color figure charges

- Immediate publication on acceptance

- Inclusion in PubMed, CAS, Scopus and Google Scholar

- Research which is freely available for redistribution 